\title{
Two remnant populations of the roofed turtle Kachuga trivittata in the upper Ayeyarwady River system, Myanmar
}

\author{
Gerald Kuchling, Win Ko Ko, Sein Aung Min, Tint Lwin, Khin Myo Myo, Thin Thin Khaing (1), \\ Thin Thin Khaing (2), Win Win Mar and Ni Ni Win
}

\begin{abstract}
The endemic roofed turtle Kachuga trivittata has been extirpated over most of its former range in the Ayeyarwady River system of Myanmar. Only two small remnant populations are known to survive. In a small stretch of the upper Chindwin River K. trivittata persists because local Shan villages traditionally ban the killing of large adult $K$. trivittata. The population has nevertheless declined dramatically during the last few years because of the erosion of the ban by migrant fishermen from central Myanmar who do not observe the local regulation, and because of the overexploitation of eggs. The traditional regulation of the Shan villages offers a basis, through its reinforcement and education of migrants, for a species recovery programme. Further actions will include the protection of nests and eggs, and eventually the banning of camps and seasonal settlements on sandbanks used by $K$. trivittata for nesting. K. trivittata also
\end{abstract}

still persists in the Dokhtawady River in a small area subjected to low exploitation pressure in the recent past because of the dangers of a frontline between the government army and an army of insurgents. The opening of this area following a truce brought this population close to extinction and a hydroelectric dam under construction will alter the ecology of this stretch of river. We propose to assess the potential use of the future impoundment lake for the recovery of this $K$. trivittata population.

Keywords Conservation status, exploitation, Kachuga trivittata, Myanmar, natural resource management, Testudines.

This paper contains supplementary material that can only be found online at http://journals.cambridge.org

\section{Introduction}

The roofed turtle Kachuga trivittata is a large-bodied, aquatic river turtle endemic to Myanmar. It is known from the Ayeyarwady, Chindwin, Sittaung and lower Thanlwin rivers, where it was historically abundant (Theobald, 1868; Maxwell, 1911; Iverson, 1992). In the Ayeyarwady River it was once common from the river delta (Maxwell, 1911) to as far north as Bahmo in Kachin State (Smith, 1931). Morris (1936) collected several nesting females near Kaung hein village at the upper Chindwin River, the largest tributary of the

Gerald Kuchling (Corresponding author) School of Animal Biology, The University of Western Australia, 35 Stirling Highway, Crawley, WA6009, Australia. E-mail kuchling@cyllene.uwa.edu.au

Win Ko Ko and Khin Myo Myo Wildlife Conservation Society, Hlaing Township, Yangon, Myanmar.

Sein Aung Min Nature and Wildlife Conservation Division, Ministry of Forestry, Forestry Department, Yangon, Myanmar.

Tint Lwin Yadanabon Zoological Garden, Mandalay, Myanmar.

Thin Thin Khaing (1), Thin Thin Khaing (2), Win Win Mar and Ni Ni Win Department of Zoology, University of Mandalay, Myanmar.

Received 16 June 2004. Revision requested 4 January 2005. Accepted 13 June 2005. First published online 10 April 2006.
Ayeyarwady, in 1935. No further specimens were collected during the rest of the 20th century. Although it is categorized as Endangered on the IUCN Red List (IUCN, 2004), the IUCN/SSC Tortoise and Freshwater Turtle Specialist Group \& Asian Turtle Trade Working Group (2000) recommended that it should be categorized as Critically Endangered or even Extinct, considering that it had not been reliably recorded since 1935 .

Recent surveys suggested that $K$. trivittata has been extirpated along the whole main channel of the Ayeyarwady River: in the delta (Thorbjarnarson et al., 2000b), along the Ayeyarwady between Pyay (Prome) and Bahmo and in the lower Chindwin up to Monywa (Platt et al., 2005) and in the upper Ayeyarwady River in the area of Myitkyina (Kuchling et al., 2006). However, during surveys of the lower Dokhtawady River, a tributary of the Ayeyarwady, in 2001 Platt et al. (2005) obtained a large empty $K$. trivittata shell from a fisherman and suggested that a remnant population of $K$. trivittata may survive in the headwaters of the river. Two empty shells of juveniles were also collected in the lower Dokhtawady in 2002 and 2003 (Kuchling et al., 2006). A preliminary survey of the upper Chindwin River, the largest tributary of the Ayeyarwady, between Homelin and Kaung hein village in 2002 suggested that $K$. trivittata has been extirpated down-river of Kaung hein, but may still persist in 
the Chindwin River from Kaung hein up-river to Khamti (Kuchling et al., 2006).

In this paper we present results of surveys along the upper Chindwin and Dokhtawady rivers in early 2004 to evaluate the species' habitat and population status, survival prospects, and any threats. We address three main questions. Firstly, which special conditions of the upper Chindwin and the Dokhtawady rivers allow these remnant $K$. trivittata populations to persist, given the extirpation of the species in other areas? Secondly, is there a threat that the same processes that extirpated the species in its former core habitats and throughout most of its range will in the future also affect these relict populations? Thirdly, what are the most appropriate conservation and recovery strategies for these populations and for the species?

\section{Study areas}

The Chindwin River arises in extreme north-western Myanmar and flows $800 \mathrm{~km}$ south before joining the Ayeyarwady River. Our study area is down-river of Khamti on the upper Chindwin (Fig. 1), a wide, meandering lowland river with a sandy bed, flood plains and exposed sand banks in the river bed during the dry season. Two main groups of fishermen operate on the upper Chindwin. Local Shan farmers, who mostly fish part-time, and full-time professional fishermen, primarily from central Myanmar, who have moved to the upper Chindwin in the last few years or decades. Fishermen typically live in temporary houses on the sandbanks of the river during the dry season (October-June). During the wet season, when the sandbanks are flooded,
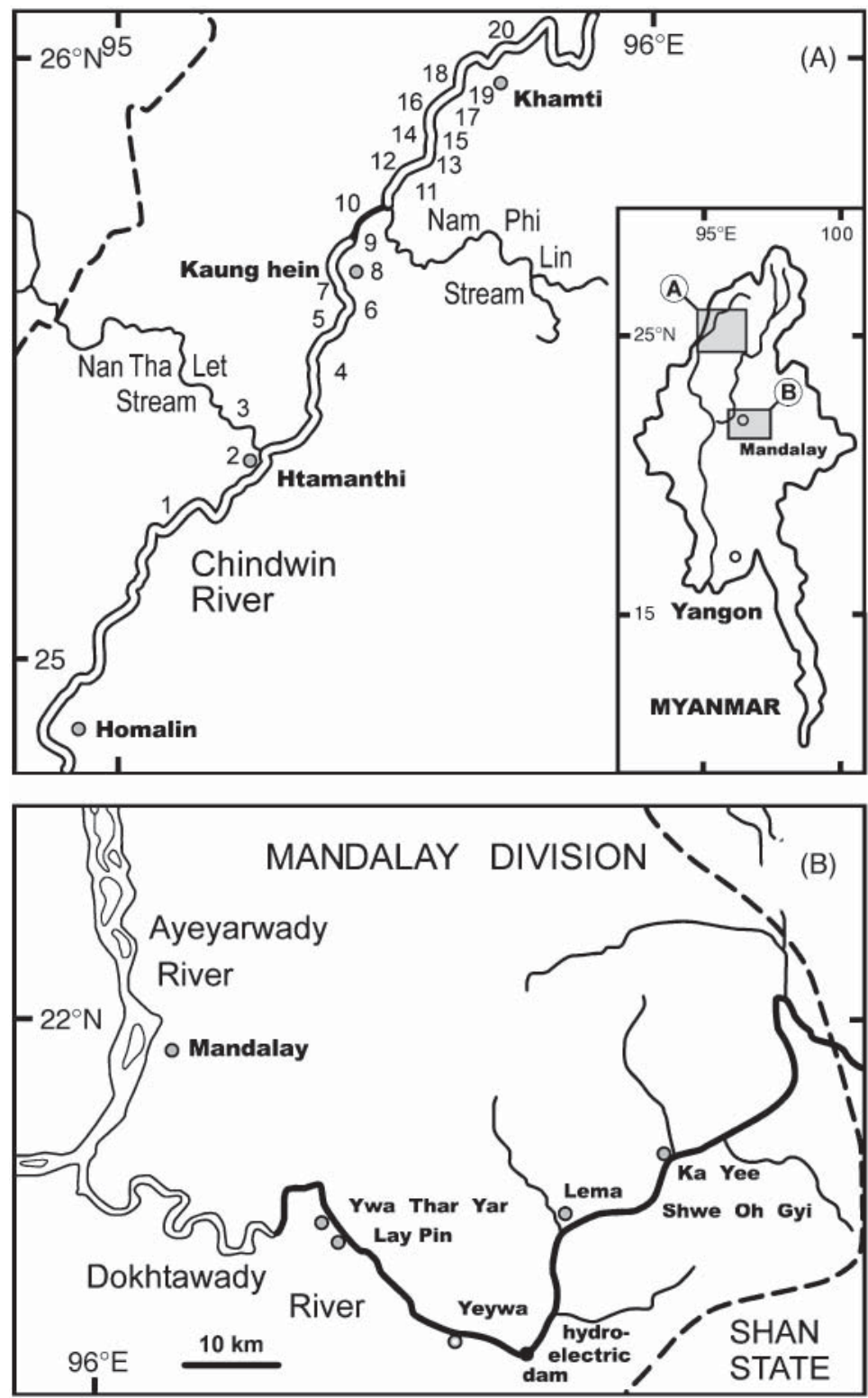

Fig. 1 (A) Map of the study area along the upper Chindwin River. The localities of interviews are indicated by numbers corresponding to those in Table 1. (B) Map of the study area along the lower Dokhtawady River, showing the localities mentioned in the text and in Table 4. The inset indicates the locations of the two main maps in Myanmar. 
they either stay in adjacent villages or move to their native towns and villages in central Myanmar.

The Dokhtawady (also known as the Myitnge or Namtu) River is an important tributary of the Ayeyarwady arising in the Shan Plateau in Shan State. Approximately $150 \mathrm{~km}$ up-river from its confluence with the Ayeyarwady it enters the Mandalay Division (Fig. 1). Our study area was at the western edge of the Shan Plateau, on the lower Dokhtawady, where the river flows generally westwards. In the up-river part of the study area the water rushes through several rapids and riffle zones in a valley surrounded by steep hills. The river bed consists mostly of gravel and boulders, interspersed with some long, deep pools with some sandbanks. In the lower part of the study area the river is a meandering lowland river with flood plains, which are used for agriculture. A hydroelectric dam is currently under construction (Fig. 1) near the centre of our study area. It is projected to inundate $c .30 \mathrm{~km}$ of river valley and will create an impoundment of c. 23,886 ha.

The lower section of the Dokhtawady in Shan State is controlled by the Shan United Army. Until a few years ago this region and the adjacent border area of Mandalay Division was subject to insurgency, was off limits to foreigners and Burmese from central Myanmar, and had a low human population. After a cease-fire between the Myanmar government and the Shan army the area was opened and large-scale movement of Burmese from central Myanmar took place along the Dokhtawady. All the fishermen we interviewed were not native to the area; most had moved from villages in central Myanmar within the last few years. Nearly all used electro-fishing equipment to catch fish and softshell turtles. One of our informants had made his living as a professional turtle hunter for the last 30 years, catching turtles mainly with baited traps.

\section{Materials and methods}

Along the upper Chindwin River between Yat Nar village and Kin Taw village we conducted 30 interviews with fishermen and villagers regarding the local occurrence of turtles and exploitation patterns and methods from 27 January to 7 February 2004, and 11 interviews at the Dokhtawady River between Ye Ywa village and a camp up-river of Ka Yee over 12-24 February 2004. Interviews lasted 1-2 hours. A set of standard questions (Appendix) was asked by the senior author and translated by the co-authors, who translated all answers. The sequence of the questions was flexible and depended upon the progress of the conversation. We were particular about species identification and enquired carefully about sizes, appearance and habits. Black and white photographs of the different turtle species and empty shells of $K$. trivitatta were used to seek confirmation of identification. Turtle shells in the possession of informants were measured and, if possible, acquired for a reference collection. In the Dokhtawady River we also dived with mask and snorkel and by using locally built underwater breathing equipment to assess the habitat.

\section{Results}

\section{Upper Chindwin River}

In a $50 \mathrm{~km}$ stretch of the upper Chindwin fishermen reported that they had caught or at least seen live, large K. trivittata and collected their eggs during 2003 (Table 1). Fishermen in villages and on sandbanks down-river and up-river of this area also knew the species, but had not caught or observed any for several years. The data in Table 1 do not include juvenile $K$. trivittata smaller than c. $30 \mathrm{~cm}$ carapace length, mainly because of the potential confusion of small K. trivittata with other hard-shelled turtle species (e.g. Cyclemys dentata). Some fishermen also claimed they have never seen the young of $K$. trivittata and obviously considered the juveniles to be a different species.

Most Shan villages in the area where $K$. trivittata persists implement a traditional ban on the killing of K. trivittata (Table 1). This ban is a long-standing tradition, in existence because $K$. trivittata is of no danger to humans, its flesh is unappealing to smell and taste according to our Shan informants, and its eggs are delicious and thus valuable. Hence, rather than killing turtles it makes more sense to release all accidentally captured individuals to ensure future egg harvests. People who kill $K$. trivittata are fined by the headmen. However, in practice Shan villagers cannot control fishermen of other ethnicities who often live on sandbanks away from the villages and usually kill, eat (despite its unappealing smell and taste) or sell this species.

Table 2 shows the specimens of $K$. trivittata we examined and/or collected in the upper Chindwin. All informants claimed that the species and its eggs are declining (Table 3). Older fishermen reported that 30 years ago many females nested on certain sandbanks over several nights, but did not recall any mass-nesting events. All informants reported that the eggs of each K. trivitatta female are not laid in one nest hole, but situated in seven holes close together in the pattern of a star sign. Some said that early in the nesting season females may lay eggs in only three or four holes. The nesting season of $K$. trivittata was reported to last from December/January to March (i.e. the cool part of the dry season).

\section{Dokhtawady River}

We examined seven specimens of $K$. trivittata captured in the Dokhtawady between Ywa Thar Yar village and Pan 
Table 1 Interview results regarding occurrence of $K$. trivittata and of $K$. trivittata eggs in villages and camps (numbers refer to locations in Fig. 1) along the upper Chindwin River in 2003.

\begin{tabular}{|c|c|c|c|c|c|c|}
\hline Village/Camp & Latitude (N) & Longitude (E) & No. seen ${ }^{1}$ & Eggs $^{2}$ & Ban on killing & Last seen \\
\hline 1 Painneikhone $^{3}$ & $25^{\circ} 12.91^{\prime}$ & $95^{\circ} 05.56^{\prime}$ & & & No & c. 1994 \\
\hline 2 Htamanthi ${ }^{3}$ & $25^{\circ} 19.62^{\prime}$ & $95^{\circ} 17.40^{\prime}$ & & & No & c. 1992 \\
\hline $3 \mathrm{Sar} \mathrm{Mi}^{4,5}$ & $25^{\circ} 22.54^{\prime}$ & $95^{\circ} 16.25^{\prime}$ & & & No & 1998 \\
\hline 4 Malin $^{3}$ & $25^{\circ} 29.52^{\prime}$ & $95^{\circ} 22.91^{\prime}$ & & & No & c. 1989 \\
\hline 5 Nauk pe & $25^{\circ} 32.26^{\prime}$ & $95^{\circ} 24.30^{\prime}$ & & & No & c. 1989 \\
\hline 6 Yat Nar Sandbank ${ }^{5}$ & $25^{\circ} 36.78^{\prime}$ & $95^{\circ} 26.70^{\prime}$ & & & No & \\
\hline 7 Na Maine Taung 5 & $25^{\circ} 38.19^{\prime}$ & $95^{\circ} 25.71^{\prime}$ & 4 & 30 & No & \\
\hline 8 Kaung hein ${ }^{5}$ & $25^{\circ} 40.45^{\prime}$ & $95^{\circ} 24.92^{\prime}$ & 5 & & Yes & \\
\hline 9 Kauak Taung ${ }^{5,6}$ & $25^{\circ} 43.78^{\prime}$ & $95^{\circ} 26.87^{\prime}$ & 10 & 300 & No & \\
\hline 10 Sandbank $^{5}$ & $25^{\circ} 47.03^{\prime}$ & $95^{\circ} 31.50^{\prime}$ & 10 & 65 & Yes & \\
\hline 11 Lin $\mathrm{Pha}^{5}$ & $25^{\circ} 48.28^{\prime}$ & $95^{\circ} 31.71^{\prime}$ & 10 & 100 & Yes & \\
\hline 12 Sandbank $^{6}$ & $25^{\circ} 49.31^{\prime}$ & $95^{\circ} 32.77^{\prime}$ & 3 & & No & \\
\hline 13 Mine Naung 5 & $25^{\circ} 50.92^{\prime}$ & $95^{\circ} 35.43^{\prime}$ & $3-4$ & 65 & Yes & \\
\hline 14 Sandbank $^{6}$ & $25^{\circ} 52.07^{\prime}$ & $95^{\circ} 34.97^{\prime}$ & & 45 & No & 2001 \\
\hline 15 Hein Soon ${ }^{5,6}$ & $25^{\circ} 52.75^{\prime}$ & $95^{\circ} 34.87^{\prime}$ & 9 & 55 & Yes/No & \\
\hline 16 Sein $\mathrm{Nan}^{5,6}$ & $25^{\circ} 56.56^{\prime}$ & $95^{\circ} 36.09^{\prime}$ & 10 & 70 & No & \\
\hline 17 Sandbank $^{5}$ & $25^{\circ} 57.00^{\prime}$ & $95^{\circ} 37.49^{\prime}$ & & 48 & No & c. 1995 \\
\hline 18 Nan Khan ${ }^{6}$ & $25^{\circ} 57.64^{\prime}$ & $95^{\circ} 39.09^{\prime}$ & & & No & 2000 \\
\hline 19 Aung Tha $a^{5,6}$ & $26^{\circ} 00.79^{\prime}$ & $95^{\circ} 39.69^{\prime}$ & & & Yes & 2000 \\
\hline 20 Kin Taw $^{6}$ & $25^{\circ} 59.48^{\prime}$ & $95^{\circ} 42.22^{\prime}$ & & & No & Never \\
\hline
\end{tabular}

${ }^{1}$ Number of large (>300 mm carapace length) K. trivittata seen or caught during 2003

${ }^{2}$ Number of K. trivittata eggs collected during 2003

${ }^{3}$ Results from interviews in July 2002 by GK and SAM

${ }^{4}$ Sar Mi village is at the Nan Tha Let Stream, a tributary of the Chindwin

${ }^{5}$ Local Shan tribe

${ }^{6}$ Migrants from the dry zone of central Myanmar

Table 2 Examined specimens of $K$. trivittata from the upper Chindwin River, with carapace length (CL), capture locality, year caught and specimen details. For latitudes and longitudes of capture localities see Table 1.

\begin{tabular}{lllll}
\hline ID & CL $(\mathrm{mm})$ & Capture locality & Year caught & Details \\
\hline $9^{1}$ & 501 & 18 Nam Khan & 2000 & Bony shell \\
$10^{1}$ & 508 & 16 Sein Nan & 2001 & Shell + scutes \\
11 & 502 & 9 Kauak Taung & c. 1994 & Bony carapace \\
12 & 512 & ? (Bought at Khamti) & 1999 & Bony shell \\
$13^{1}$ & 515 & 3 Sar Mi (Nan Tha Let Stream) & 1998 & Bony shell \\
$15^{2,3}$ & 305 & ? (Confiscated from trader at Po Aung) & 2004 & Live male \\
$16^{2,3}$ & 510 & ?(Confiscated from trader at Po Aung) & 2004 & Live female \\
\hline
\end{tabular}

${ }^{1}$ Acquired for reference collection

${ }^{2}$ Specimens provided by U Myint Aung, Park Warden, Forestry Department Office, Homelin

${ }^{3}$ Transferred to captive breeding colony at Yadanabon Zoo

Table 3 Examples of decline of $K$. trivittata and their eggs along the upper Chindwin River, estimated by local people.

\begin{tabular}{lcccc}
\hline & 2003 & $\begin{array}{l}5 \text { years } \\
\text { ago }\end{array}$ & $\begin{array}{l}10 \text { years } \\
\text { ago }\end{array}$ & $\begin{array}{l}30 \text { years } \\
\text { ago }\end{array}$ \\
\hline $\begin{array}{c}\text { No. of adult K. trivittata } \\
\text { observed at Hein Soon }\end{array}$ & 9 & & 45 & \\
$\begin{array}{c}\text { No of } \text {. trivittata eggs } \\
\text { collected, Hein Soon }\end{array}$ & 55 & 550 & \\
$\begin{array}{c}\text { No. of adult K. trivittata } \\
\text { observed between } \\
\text { Kauak Taung \& Lin Pha }\end{array}$ & 50 & & 200 & 1,000 \\
$\begin{array}{c}\text { No. of K. trivittata eggs } \\
\text { collected, Lin Pha }\end{array}$ & 100 & 300 & 1,000 & \\
\hline
\end{tabular}

Pu Chaung (c. $71 \mathrm{~km}$; Fig. 1; Table 4). Three of the fishermen we interviewed reported that they had each caught a large ( $>40 \mathrm{~cm}$ carapace length) K. trivittata during 2001 at or near the Shwe Oh Gyi sandbank but had not seen a large turtle since. Many informants believed juveniles were a different species. Although many informants indicated they eat adult and juvenile $K$. trivittata, most do not collect eggs and are not aware of nest sites.

Two professional divers who recover teak logs lost in the river reported they occasionally see K. trivittata (approximately two times per year) during their dives. Large adults are mainly caught or observed close to 
Table 4 Specimens of K. trivittata collected at the Dokhtawady River since 2001, with sex, carapace length (CL), locality, year caught and specimen details.

\begin{tabular}{|c|c|c|c|c|c|c|c|}
\hline ID & Sex & $\mathrm{CL}(\mathrm{mm})$ & Capture locality & Latitude $(\mathrm{N})$ & Longitude (E) & Year caught & Details \\
\hline $1^{1}$ & Female & 473 & Shwe Oh Gyi² & $21^{\circ} 49.05^{\prime}$ & $96^{\circ} 35.59^{\prime}$ & 2001 & Shell with scutes \\
\hline $2^{3}$ & Juv. & 232 & Ywa Thar Yar & $21^{\circ} 48.58^{\prime}$ & $96^{\circ} 15.50^{\prime}$ & 2002 & Carapace + scutes \\
\hline $7^{4}$ & Male & 292 & Ka Yee & $21^{\circ} 52.00^{\prime}$ & $96^{\circ} 37.23^{\prime}$ & Jan. 2003 & Shell with scutes \\
\hline $8^{4,5}$ & Juv. & 198 & Lay Pin & $21^{\circ} 47.11^{\prime}$ & $96^{\circ} 16.29^{\prime}$ & Oct. 2003 & Live juv. male \\
\hline $14^{4}$ & Juv. & c. 257 & Lay Pin & $21^{\circ} 47.11^{\prime}$ & $96^{\circ} 16.29^{\prime}$ & Oct. 2003 & Shell remains, skull \\
\hline $18^{4,5}$ & Juv. & 120 & Pan Pu Chaung & $21^{\circ} 52.86^{\prime}$ & $96^{\circ} 41^{\prime \prime} 01^{\prime}$ & May 2004 & Live juv. female \\
\hline $19^{4,5}$ & Juv. & 236 & Lay Pin & $21^{\circ} 47.11^{\prime}$ & $96^{\circ} 16.29^{\prime}$ & Sep. 2004 & Live juv. male \\
\hline
\end{tabular}

${ }^{1}$ Specimen collected by Platt et al. (2005)

${ }^{2}$ According to interview in present study

${ }^{3}$ Specimen referred to in Kuchling et al. (2006)

${ }^{4}$ Specimens collected by Thin Thin Khaing (1) \& Ni Ni Win

${ }^{5}$ Transferred to captive breeding colony at Yadanabon Zoo

sandbanks in deep river pools or holes, called ei, where the water flows relatively slowly. We hired the divers and dived with them at river pools at the Shwe Oh Gyi sandbank, but did not see any turtles. Many pools are deeper than $15 \mathrm{~m}$, and in many places we could not reach the bottom; thus, turtles may have been present but undetected in the deeper areas of the pools.

\section{Discussion}

K. trivittata was once common and occurred in high numbers throughout the Ayeyarwady River system, with the exception of its mountainous headwaters, but today only a few small remnant populations survive in marginal habitat close to the boundaries of the species' former distribution. The major threat to the persistence of $K$. trivitatta is the over-harvesting of adult turtles and their eggs for human consumption (Thorbjarnarson et al., 2000b; Platt et al., 2005; Kuchling et al., 2006). Most K. trivittata and/or their eggs are consumed locally in the villages or sold at markets in nearby towns. International trade seems to play only a minor role in the disappearance of $K$. trivittata. Despite the massive illegal trade of turtles from Myanmar into China (Platt et al., 2000), relatively few $K$. trivittata have been recorded in Chinese markets. The monetary value of $K$. trivittata (as opposed to softshell turtles) is generally too low to make it worthwhile to sell the species to traders.

River turtles at relatively low densities are difficult to locate. In such cases interviewing local fishermen, turtle hunters and divers is a suitable method to gain information (Kuchling, 1997; Kuchling et al., 2006). A rigorous and structured interview technique is imperative if the objective is to use the results for conservation planning. For example, Platt (2001) collected a single shell of an adult $K$. trivittata from a fisherman at Ye Ywa village (Table 4) and reported that this turtle was captured 'from a sandbar at the headwaters of the Dokhtawady near the Chinese border'. This information was surprising because the small, fast flowing mountain creeks and streams there do not appear to be $K$. trivittata habitat. Using our questionnaire we re-interviewed the fisherman (U Htoo) who had originally captured this specimen and learned that he had actually captured it at the Shwe Oh Gyi sandbank (Table 4), c. $250 \mathrm{~km}$ from the closest Chinese border. This profound discrepancy demonstrates the potentially low reliability of informal interviews. Although it is difficult to determine the accuracy of our interviews, consistencies of information from separate interviews, as well as the specimens we examined, support the reliability of our interview results.

The upper Chindwin is not a pristine habitat. It has a relatively dense human population and has been degraded by gold mining, deforestation, agriculture, overfishing and siltation. For this reason Platt et al. (2005) asserted that the upper Chindwin is 'unlikely to support significant numbers of $K$. trivittata'. Our data indicate, however, that although the species has been extirpated (apart from occasional dispersing juveniles) throughout most of the Chindwin, a breeding population of $K$. trivittata persists in a stretch of $c .50 \mathrm{~km}$ but at a reduced density. This is the largest population presently known and seems to persist because of the traditional ban on the killing of adult $K$. trivittata in Shan villages.

Most turtles, including $K$. trivittata, have delayed sexual maturity, high longevity, iteroparity, and high adult survivorship, combined with relatively high clutch sizes and low egg and hatchling survival (Kuchling, 1999). Harvesting systems based on the collection of eggs are thus less likely to have negative impacts than those based on killing adults and large juveniles (Thorbjarnarson et al., 2000a). Although the traditional custom of the Shan villages not to kill large adults is not sufficient to make the exploitation of the species sustainable, it has allowed the species to persist. This offers a chance to support Shan villages to improve their 
traditional natural resource management and to coerce immigrant fishermen to observe the local regulations, thereby promoting the recovery of $K$. trivittata.

$K$. trivittata has persisted in the Dokhtawady for different reasons. No Shan fishermen operate along the surveyed river stretch and no traditional regulations exist regarding turtle exploitation. A breeding population persists, or at least persisted until recently, in the border area between the Mandalay Division and Shan State. Until c. 3 years ago there was only limited exploitation in the area up-river of Salin village and the hydroelectric dam under construction, because of the dangers associated with the frontline between the government army and a powerful army of insurgents. The main threat to the remnant $K$. trivittata population in the Dokhtawady now comes from the massive influx of people from central Myanmar into the area following the truce between the government and the Shan army. The entire area we surveyed has been heavily deforested in the past 3 years and fish, prawns and softshell turtles have been largely removed from the river through electro-fishing. Commercial electro-fishing is generally illegal in Myanmar, but this law is not enforced on the Dokhtawady.

Exploitation and extirpation patterns of the river turtle Erymnochelys madagascariensis showed that, in habitats where fishing pressure suddenly increases because of an influx of people with better fishing technologies, adults are the first cohort to be extirpated. Although no further recruitment of hatchlings takes place after this event, turtles are still caught for several years because small size classes from previous reproductive seasons are still growing to a size at which they become attractive for human consumption. Once all these growing turtles have also been removed, extinction is abrupt (Kuchling, 1997). This scenario currently seems to operate in the Dokhtawady. Although we did not obtain reports that large adult $K$. trivittata have been caught or observed during the last 3 years, juveniles were still being caught.

The status of $K$. trivittata is the most precarious of all the endemic turtles in Myanmar. The traditional regulation regarding $K$. trivittata along the upper Chindwin provides a unique opportunity for the implementation of a comprehensive species recovery programme (Kuchling, 2003, 2004). Proposed conservation actions include: (1) reinforcement of the traditional ban on killing adult K. trivittata; (2) education of migrants to observe this traditional regulation; (3) assessment of status and reproductive output of $K$. trivittata (and of the other large, endemic river turtles Chitra vandijki and Nilssonia formosa) through a nest, egg and hatchling monitoring programme that will include direct remuneration of local people for their help in finding nests; (4) the protection of nests and eggs, and headstarting of wild hatchlings at Yadanabon Zoo; (5) the banning of camps and seasonal settlements on sandbanks used by
K. trivittata for nesting. In the Dokhtawady K. trivittata seems to be close to extirpation and in a few years the hydroelectric dam will greatly alter the ecology of this stretch of river. The impoundment lake will stretch up-river to approximately the area of the Shwe Oh Gyi sandbank that seems to be the primary remaining breeding area of $K$. trivittata in the Dokhtawady. The large turtles generally prefer deep, slow-flowing river sections. Thus the impoundment itself may not be catastrophic for the species, particularly if some nesting sandbanks remain up-river of the future lake and if human disturbance of $K$. trivittata in the area can be prevented or minimized. An education programme for local people will highlight the benefits of turtle conservation. Research on movement and dispersal patterns of $K$. trivittata prior to the impoundment will be the basis for management recommendations regarding the use of the future impoundment in the recovery of this $K$. trivittata population (Kuchling, 2004). Recovery will be achieved by reintroducing turtles bred at Yadanabon Zoo (Kuchling, 2003).

\section{Acknowledgements}

This survey was funded by the Wildlife Conservation Society. We thank John Thorbjarnarson and U Than Myint, WCS Myanmar, for help with logistics, and U Khin Maung Zaw, Director, Nature and Wildlife Conservation Division, Myanmar Forestry Department and Professor Khin Mya Mya, University of Mandalay, for approving and supporting this project. For their hospitality and technical help we thank U Myint Aung, Park Warden, Forestry Department Office, Homelin, and U Maung Chit, Assistant Director, Yadanabon Zoological Garden. We thank Michael Werner for help with the preparation of the maps.

\section{References}

IUCN/SSC Tortoise and Freshwater Turtle Group \& Asian Turtle Trade Working Group (2000) Recommended changes to 1996 IUCN Red List status of Asian turtle species. In Asian Turtle Trade: Proceedings of a Workshop on Conservation and Trade of Freshwater Turtles and Tortoises in Asia (eds P.P. Van Dijk, B.L. Stuart \& A.G.J. Rhodin). Chelonian Research Monographs, 2, 156-164.

IUCN (2004) IUCN Red List of Threatened Species. IUCN, Gland, Switzerland [http://www.redlist.org, accessed 14 November 2005].

Iverson, J.B. (1992) A Revised Checklist with Distribution Maps of the Turtles of the World. Privately published, Richmond, USA.

Kuchling, G. (1997) Patterns of exploitation, decline, and extinction of Erymnochelys madagascariensis: implications for the conservation of the species. In Conservation, Management and Restoration of Tortoises and Turtles - An International Conference (ed. J. Van Abbema), pp. 113-117. New York Turtle and Tortoise Society, New York, USA. 
Kuchling, G. (1999) The Reproductive Biology of the Chelonia. Zoophysiology Volume 38. Springer, Berlin/Heidelberg, Germany.

Kuchling, G. (2003) Species Survival Plan for the Critically Endangered Roofed Turtle Kachuga trivittata Part I: Assurance Colony at the Yadanabon Zoological Garden, Mandalay. Unpublished Report. Chelonia Enterprises, Perth, Australia.

Kuchling, G. (2004) Species Survival Plan for the Critically Endangered Roofed Turtle Kachuga trivittata Part B: Conservation Strategies for the Wild Populations at the Upper Chindwin River and the Dokhtawady River. Unpublished Report. Chelonia Enterprises, Perth, Australia.

Kuchling, G., Tint Lwin \& Sein Aung Min (2006) Interview based surveys on exploitation and status of endemic river turtles in upper Myanmar and implications for their conservation. In Proceedings of the 2nd International Congress on Chelonian Conservation, Senegal, June 2003. SOPTOM, Gonfaron, France.

Maxwell, F.D. (1911) Reports on Inland and Sea Fisheries in the Thongwa, Myaungmya, and Bassein Districts and the Turtle-banks of the Irrawaddy Division. Government Printing Office, Rangoon, Burma.

Morris, R.C. (1936) The Vernay-Hopwood upper Chindwin expedition. Journal of the Bombay Natural History Society, $38,647-671$.

Platt, S.G. (2001) An Investigation into the Conservation Status of Kachuga trivittata and Other Turtles of the Upper Ayeyarwady and Dokhtawady (Myitnge) Rivers, Myanmar. Unpublished Report, Wildlife Conservation Society, Phnom Penh, Cambodia.

Platt, S.G., Kalyar \& Win Ko Ko (2000) Exploitation and conservation status of tortoises and freshwater turtles in Myanmar. In Asian Turtle Trade: Proceedings of a Workshop on Conservation and Trade of Freshwater Turtles and Tortoises in Asia (eds P.P.Van Dijk, B.L. Stuart \& A.G.J. Rhodin). Chelonian Research Monographs, 2, 95-100.

Platt, S.G., Win Ko Ko, Lay Lay Khaing, Khin Myo Myo, Kalyar \& Rainwater T.R. (2005) Noteworthy records and comments on selected species of turtles from the Ayeyarwady, Chindwin, and Dokhtawady Rivers, Myanmar. Chelonian Conservation and Biology, 4, 942-948.

Smith, M.A. (1931) The Fauna of British India, including Ceylon and Burma - Reptilia and Amphibia, Volume 1. Loricata, Testudines. Taylor \& Francis, London, UK.

Theobald, W. (1868) Catalogue of reptiles of British Burma, embracing the provinces of Pegu, Martaban, and Tenasserim; with description of new or little-known species. Journal of the Linnean Society, Zoology, 10, 4-67.
Thorbjarnarson, J.B., Lagueux, C.J., Bolze, D., Klemens, M.W. \& Meylan, A.B. (2000a) Human use of turtles: a worldwide perspective. In Turtle Conservation (ed. M.W. Klemens), pp. 33-84. Smithsonian Institution Press, Washington, USA. Thorbjarnarson, J.B., Platt, S.G. \& Saw Tun Khaing (2000b) Conservation status of freshwater turtles in Meinmahla Kyun Wildlife Sanctuary and vicinity, Myanmar. Natural History Bulletin of the Siam Society, 48, 185-191.

\section{Appendix}

The appendix for this article is available online at http:/ / journals.cambridge.org

\section{Biographical sketches}

Gerald Kuchling is Principal Investigator of the Western Swamp Turtle Pseudemydura umbrina Recovery Team in Western Australia. He planned, designed and implemented a conservation programme for the critically endangered river turtle Erymnochelys madagascariensis and collaborates on tortoise and turtle research in Madagascar, South Africa and Malaysia.

Win Ko Ko is Myanmar's foremost turtle and crocodile surveyor and specialist and leads the WCS Myanmar Turtle Program Team.

Sein Aung Min is wildlife manager and park warden at Mount Kyaiktiyo. He has extensive experience in wildlife surveys and monitoring and was a partner in the 2002 survey that rediscovered Kachuga trivittata.

Zoo veterinarian Tint Lwin specializes in the captive breeding of tortoises and turtles, in particular the critically endangered Mynamar endemics Geochelone platynota and Kachuga trivittata.

Khin Myo Myo has research experience with sea turtles and crocodiles. She is now a staff member of the Chindwin River Project and leads a Village Awareness Program to encourage local participation in turtle conservation.

Thin Thin Khaing (1), Thin Thin Khaing (2), Win Win Mar and $\mathrm{Ni} \mathrm{Ni}$ Win are carrying out research on the ecology of Myanmar's endemic river turtles. 